\title{
Crystal structure, thermal behavior and spectroscopic studies of a new organic hydrogen arsenate
}

\author{
Sami Soukrata ${ }^{a^{*}}$, Mohamed Belhouchet ${ }^{\mathrm{a}}$, Karim Adil ${ }^{\mathrm{b}}$ and Tahar Mhiri ${ }^{\mathrm{a}}$ \\ ${ }^{a}$ Laboratoire Physico-Chimie de l'Etat Solide. Département de Chimie. Faculté des Sciences de Sfax.
} Université de Sfax. 3018 Sfax. Tunisia

${ }^{\mathrm{b}}$ Laboratoire des Oxydes et Fluorures, UMR 6010 CNRS, Faculté des Sciences et Techniques, Université du Maine, Avenue O. Messiaen, 72085 Le Mans Cedex 9, France

*Corresponding e-mail: soukratasami@yahoo.fr

\begin{abstract}
The present paper undertakes the study of a title organic-inorganic hybrid material 2-amino-3-benzyloxy pyridinium dihydrogenmonoarsenate, $\left[\mathrm{C}_{12} \mathrm{H}_{13} \mathrm{~N}_{2} \mathrm{O}_{\mathrm{H}} \mathrm{H}_{2} \mathrm{AsO}_{4}\right.$, which has been synthesized by slow evaporation at room temperature using 2-amino-3-benzyloxypyridine as the structure-directing agent. The structure was determined by single-crystal X-ray diffraction at $296 \mathrm{~K}$. This compound is crystallized in the noncentrosymmetric orthorhombic space group $P 2{ }_{1} 2,2$, with the lattice parameters $a=4.89(7), b=10.41(1), c=26.79$ (3) $\AA, V=1364.3$ (3) $\AA^{3}$, and $Z=4$. The crystal structure has been determined and refined to $R_{1}=0.0363$ and $\mathrm{wR}_{2}=0.1246$ using 5438 independent reflections. The atomic arrangement can be described by infinite anionic chains running parallel to the [100] direction. The organic entities are located between these chains. $\mathrm{H}$-bonds connecting the different species play an important role in the one-dimensional network cohesion. This compound is also characterized by solid-state ${ }^{13} \mathrm{C}$ MAS NMR, IR, Raman spectroscopy and TG-ATD thermal analysis. Moreover, protonic conduction of this compound determined by impedance has been studied in the temperature range 299 - $403 \mathrm{~K}$.
\end{abstract}

Keywords: Chemical synthesis, Crystal structure, Thermal behavior, Infrared spectroscopy, Raman spectroscopy.

\section{Council for Innovative Research}

Peer Review Research Publishing System

\section{Journal: Journal of Advances in Chemistry}

Vol. 9, No. 2 


\section{INTRODUCTION}

Recently, many chemists and physicists have shown increasing interest in the study of the new hybrid compounds having many practical and potential applications in various fields, such as biomolecular science, catalysis, fuel cell, liquid crystal-material development and quadratic nonlinear optics [1-3]. Among these hybrid compounds, organic arsenates are particularly significant and their anions are interconnected by strong hydrogen bonds so as to build infinite networks with various geometries such as ribbons [4], chains [5], or layers [6-7].

Actually, the influence of hydrogen bonds on the chemical and structural features of the hybrid materials provides it with remarkable properties such as structural properties. For the aforementioned reasons, this compound is considered to be suitable for the present research work. In fact, the latter allows for the finding of a new crystal whose chemical preparation, crystal structure, thermal behavior, NMR, Raman and IR spectroscopy are combined to provide a description of the new synthesized organic arsenate.

\section{EXPERIMENTAL}

\subsection{Synthesis and characterization}

The title compound, $\left[\mathrm{C}_{12} \mathrm{H}_{13} \mathrm{~N}_{2} \mathrm{O}\right] \mathrm{H}_{2} \mathrm{AsO}_{4}$, was prepared from an alcoholic solution $(20 \mathrm{~mL})$ containing 2-amino-3benzyloxy pyridine (99\%) $(0.2 \mathrm{~g}, 0.99 \mathrm{mmol})$ dissolved in ethanol and arsenic acid $\mathrm{H}_{3} \mathrm{AsO}_{4}(0.56 \mathrm{~g}, 3.94 \mathrm{mmol})(99.99 \%)$. This mixture was stirred for $30 \mathrm{~min}$ and then slowly evaporated at room temperature for several days until the formation of transparent plate single crystals of good quality and suitable dimensions for crystallographic study.

\section{2. $X$ - ray structure determination}

A suitable crystal was carefully selected under a polarizing microscope and mounted at the end of a thin glass fiber. Crystal structure determination was performed using a Bruker APEX-II Quazar diffractometer which uses graphite monochromatized MoK $\alpha$ radiation $(\lambda=0.71073 \AA)$. The unit cell parameters, optimized by least-squares refinement, were calculated and refined using the indexation of collected intensities. The total number of the measured reflections was 13385 among which 5438 were independent and 2879 had intensity $\mathrm{I}>2 \sigma(\mathrm{I})$. The structure of the $\left[\mathrm{C}_{12} \mathrm{H}_{13} \mathrm{~N}_{2} \mathrm{O}\right] \mathrm{H}_{2} \mathrm{AsO}_{4}$ compound belongs to space group $P 2_{1} 2_{1} 2_{1}$. Arsenic atom positions were located using SHELXS-97 [8] .The oxygen (O), carbon $(\mathrm{C})$, and nitrogen $(\mathrm{N})$ atom positions, were deduced from difference Fourier maps during the refinement. The hydrogen atoms of the $\mathrm{CH}_{2}, \mathrm{NH}_{2}, \mathrm{CH}$ and $\mathrm{NH}$ have been fixed geometrically by the appropriate instructions of the SHELXL-97 program [9] and held in the riding mode. The final discrepancy factors $R_{1}$ and $w R_{2}$ were found to be 0.0363 and 0.1246, respectively. Crystal data and experimental parameters used for the intensity data collection are summarized in Table 1. The crystallographic data for the structure reported in this work have been deposited into the Cambridge Crystallographic Data Center as supplementary publication No 927658. The copies of the data can be obtained, free of charge, on application to the CCDC, 12 Union Road, Cambridge CB 12EZ, UK. E-mail deposit@ccdc.cam.ac.uk.

\subsection{General experimental section}

The NMR spectrum was recorded on Bruker DSX-300 spectrometer operating at $75.47 \mathrm{MHz}$ for ${ }^{13} \mathrm{C}$ with a classical 4-mm probe head allowing spinning rates up to $10 \mathrm{kHz}$. The chemical shifts were referenced relatively to tetramethylsilane (TMS). In all cases, it was checked that there was a sufficient delay between the scans allowing a full relaxation of the nuclei.

Concerning the Fourier transform infrared (FT-IR) measurements were performed at room temperature, on a Perkin-Elmer FT-IR Paragon 1000 PC spectrometer over the $4000-400 \mathrm{~cm}^{-1}$ region, in a $\mathrm{KBr}$ pellet.

Furthermore, Raman spectra were measured with a LABRAMHR- 800 triple monochromator at room temperature under a $50 \times$ LF objective microscope. An He-Ne ion laser operating at about $20 \mathrm{~mW}$ was used (on the sample) as an excitation source $(514.5 \mathrm{~nm})$, with a spectral steps of $3 \mathrm{~cm}^{-1}$. The thermal analyses were performed by means DTA/TGA investigations were performed using a multi-module 92 SETARAM analyzer operating from room temperature up to $450^{\circ} \mathrm{C}$ at a constant rate of $5^{\circ} \mathrm{C} \mathrm{min}{ }^{-1}$ and Differential scanning calorimetry (DSC 30 device of Mettler-Toledo) instrument with a heating rate of $10^{\circ} \mathrm{C} / \mathrm{min}$ up to $300^{\circ} \mathrm{C}$ under constant Argon flow. 
Table 1 Crystal data and experimental parameters used for the intensity data collection, strategy and final results of the structure determination.

\begin{tabular}{|c|c|}
\hline Empirical Formula & {$\left[\mathrm{C}_{12} \mathrm{H}_{13} \mathrm{~N}_{2} \mathrm{O}\right] \mathrm{H}_{2} \mathrm{AsO}_{4}$} \\
\hline Formula Weight $\left(\mathrm{g} \cdot \mathrm{mol}^{-1}\right)$ & 342.18 \\
\hline Crystal System / Space Group & Orthorhombic / $\mathrm{P} 2{ }_{1} 2_{1} 2_{1}$ \\
\hline $\mathrm{a} / \AA$ & $4.89(7)$ \\
\hline $\mathrm{b} / \AA$ & $10.41(1)$ \\
\hline c / $\AA$ & $26.79(3)$ \\
\hline $\mathrm{V} / \AA^{3}$ & $1364.3(3)$ \\
\hline $\mathrm{Z}$ & 4 \\
\hline$D_{\text {calc }}\left(\mathrm{g} / \mathrm{cm}^{3}\right)$ & 1.666 \\
\hline$\mu\left(\mathrm{mm}^{-1}\right)$ & 2.51 \\
\hline Crystal size (mm) & $0.3 \times 0.2 \times 0.1$ \\
\hline Color / Shape & Transparent / Plate \\
\hline Temperature $(\mathrm{K})$ & $296(2)$ \\
\hline Theta range for collection & $1.5-35.3$ \\
\hline Reflections collected & 13385 \\
\hline Independent reflections & 5438 \\
\hline Data/restraints/parameters & $2879 / 0 / 183$ \\
\hline Goodness of fit on $\mathrm{F}^{2}$ & 1.00 \\
\hline Final $R$ indices $[I>2 \sigma(I)]$ & 0.0363 \\
\hline $\mathrm{R}$ indices (all data) & 0.1246 \\
\hline Largest difference peak/hole & $-0.85 / 0.60$ \\
\hline
\end{tabular}

\subsection{Electrical measurements}

The electrical measurements were performed by means of a two-electrode configuration. Besides, the polycrystalline $\left[\mathrm{C}_{12} \mathrm{H}_{13} \mathrm{~N}_{2} \mathrm{O}\right] \mathrm{H}_{2} \mathrm{PO}_{4}$ sample was pressed into pellets of $8 \mathrm{~mm}$ in diameter and $1.1 \mathrm{~mm}$ in thickness using 3 tons $/ \mathrm{cm}^{2}$ uniaxial pressures. The ac conductivity measurements were performed with a Tegam 3550 impedance analyser $(209 \mathrm{~Hz}$ to $5 \mathrm{MHz}$ ) which was also interfaced with a computer and a temperature controller. Measurements were taken at temperatures from 293 to $403 \mathrm{~K}$.

\section{RESULTS AND DISCUSSION}

\subsection{Thermal Behavior}

Two curves corresponding to DTA and TGA analyses in open air are given in Fig. 1. Concerning the DTA curve, it shows that this compound undergoes a series of thermal events. The first two peaks at $144{ }^{\circ} \mathrm{C}$ and $155{ }^{\circ} \mathrm{C}$ are accompanied with a weight loss which is obviously observed in the TGA curve. This weight loss corresponds to the removal of a water molecule resulting from a dehydroxylation reaction due to the presence of terminal As-OH groups (\% water: experimental 5.59 calculated 5.26). With respect to the TGA curve, it shows a continuous weight loss in the range of $183-450{ }^{\circ} \mathrm{C}$ characterized by two endothermic peaks at 197 and $204^{\circ} \mathrm{C}$ observed on the DTA curve. The corresponding phenomena could be interpreted by a $\left[\mathrm{C}_{12} \mathrm{H}_{13} \mathrm{~N}_{2} \mathrm{O}\right]^{+}$degradation, leading to a viscous matter of polyarsenic acids with a carbon black residue. This is confirmed by differential scanning calorimetry DSC. Fig. 2 performed between 25 and $300^{\circ} \mathrm{C}$ which does not show any phase transition before the melting point. 


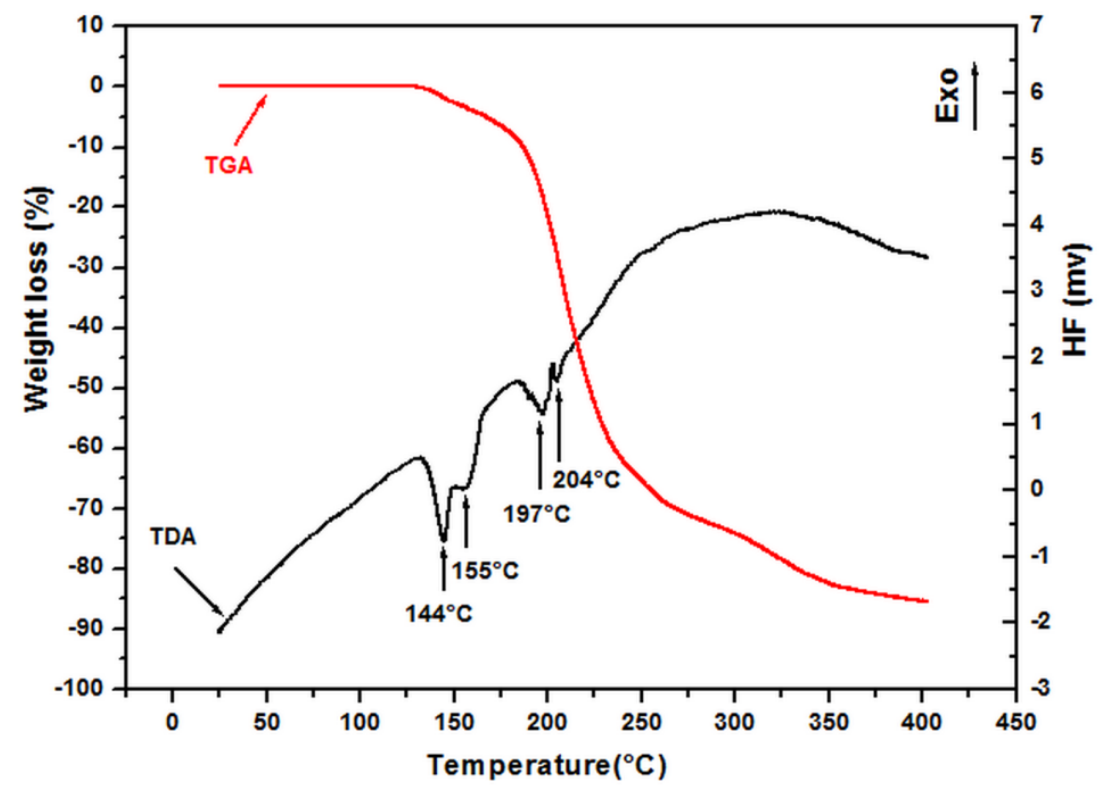

Fig. 1 DTA and TGA curves of $\left[\mathrm{C}_{12} \mathrm{H}_{13} \mathrm{~N}_{2} \mathrm{O}\right] \mathrm{H}_{2} \mathrm{AsO}_{4}$.

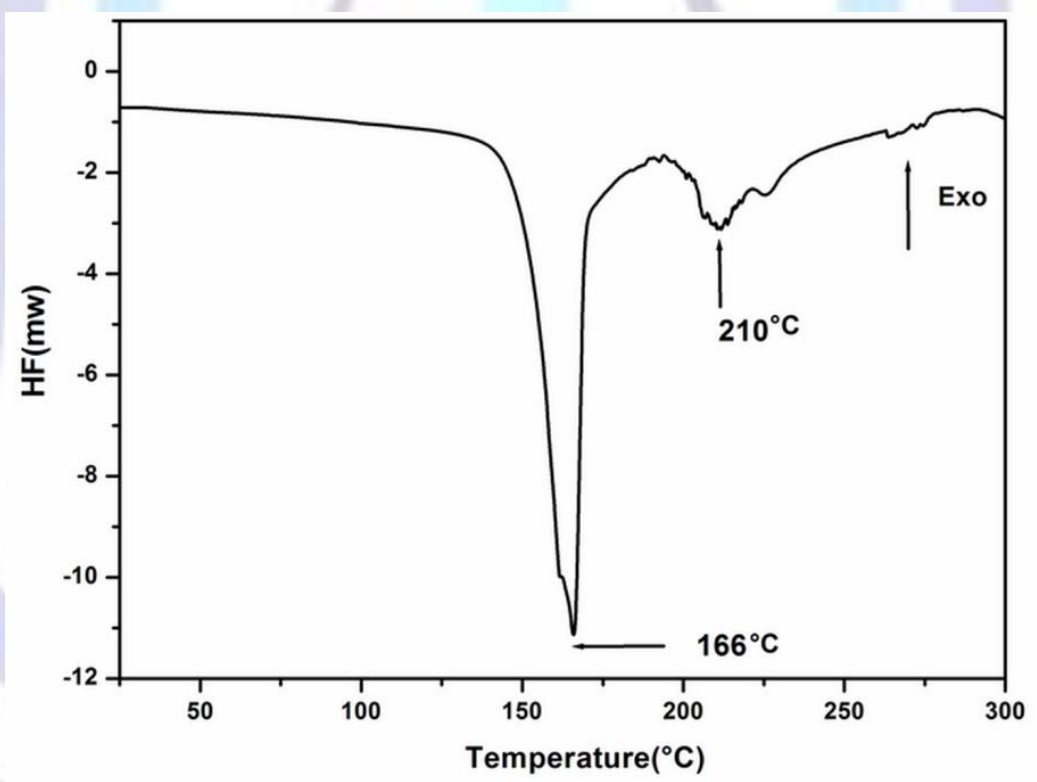

Fig. 2 DSC curve of $\left[\mathrm{C}_{12} \mathrm{H}_{13} \mathrm{~N}_{2} \mathrm{O}\right] \mathrm{H}_{2} \mathrm{AsO}_{4}$.

\subsection{Structure description}

The structure consists of one arsenate anion and one organic cation (Fig. 3). Fig. 4 displays the crystal structure viewed along the $\mathrm{b}$ direction. This projection shows that the dihydrogen arsenate anions are linked through short $\mathrm{O}-\mathrm{H}$...O hydrogen bonds, forming infinite chains running parallel to the [100] direction. Within the inorganic chains, the $\mathrm{H}_{2} \mathrm{AsO}{ }_{4}$ entity has two types of As-O distances depending on whether $\mathrm{O}$ atoms are hydrogen donors [1.702 (4)-1.708 (3) $\AA$ ] or acceptors [1.662 (4)-1.659 (3) A]. As expected, the As-OH distances are significantly longer than the other As-O distances. The average values of the As-O distances and the $\mathrm{O}-\mathrm{As}-\mathrm{O}$ angles are $1.682(4) \AA$ and $109.4(2)^{\circ}$, respectively, Table 2. These similar geometrical features have also been noticed in other crystal structures [10,11]. The $\left[\mathrm{H}_{2} \mathrm{AsO}_{4}{ }^{-}\right]$anions are assembled in dimers with the formula $\left[\mathrm{H}_{4} \mathrm{As}_{2} \mathrm{O}_{8}\right]^{2-}$ through one hydrogen bond $[\mathrm{O}(4)-\mathrm{H}(\mathrm{O} 4) \ldots \mathrm{O}(1)]$. Such dimers are connected themselves through three hydrogen bonds [two bonds of the type $\mathrm{O}(2)-\mathrm{H}(\mathrm{O} 2) \ldots \mathrm{O}(3)$ and one of the type $\mathrm{O}(4)-\mathrm{H}(\mathrm{O} 4) \ldots \mathrm{O}(1)]$, forming infinite chains with the formula $\left[\mathrm{H}_{4} \mathrm{As}_{2} \mathrm{O}_{8}\right]_{\mathrm{n}}{ }^{2 \mathrm{n}-}$. 


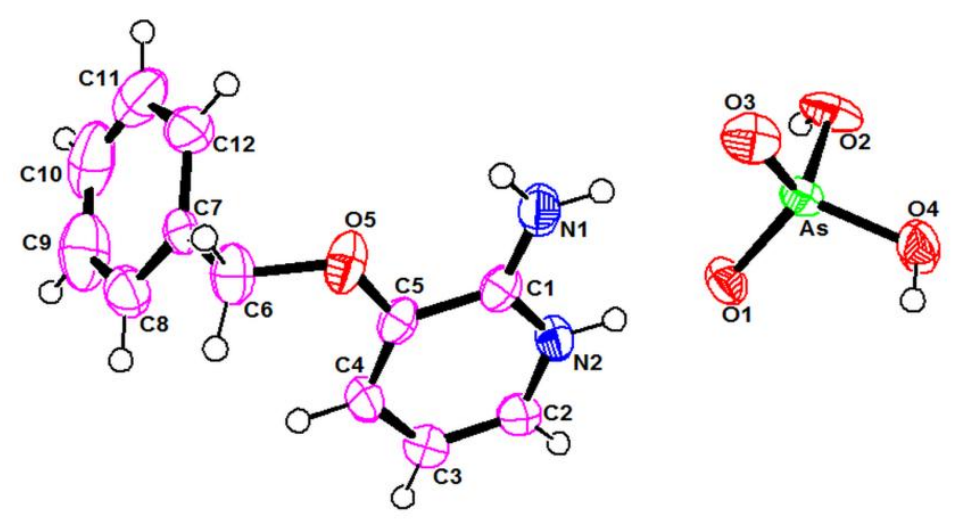

Fig. 3 Asymmetric unit of $\left[\mathrm{C}_{12} \mathrm{H}_{13} \mathrm{~N}_{2} \mathrm{O}\right] \mathrm{H}_{2} \mathrm{AsO}_{4}$.

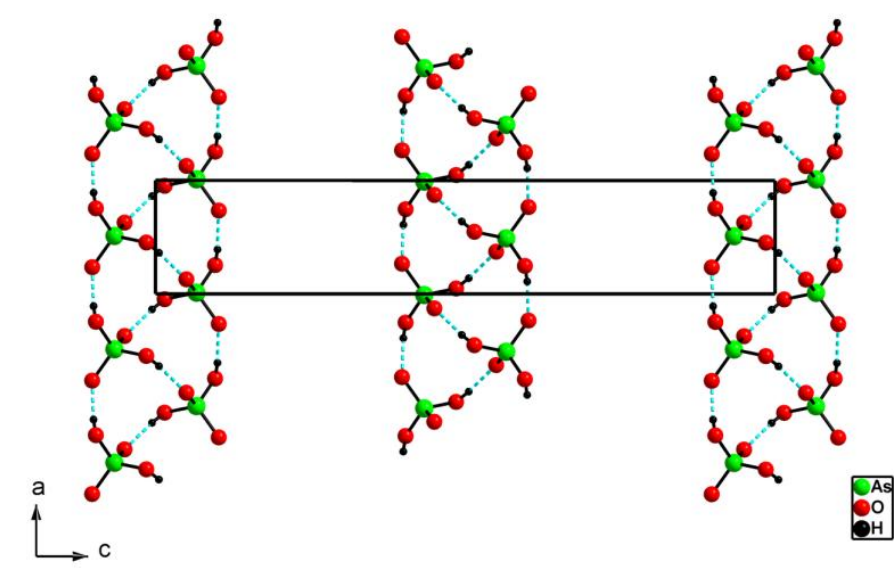

Fig. 4 Projection along the b-axis of the inorganic entities of $\left[\mathrm{C}_{12} \mathrm{H}_{13} \mathrm{~N}_{2} \mathrm{O}\right] \mathrm{H}_{2} \mathrm{AsO} \mathrm{O}_{4}$.

It is worthwhile noting that the $\mathrm{O} \ldots \mathrm{O}$ distances involved in the hydrogen bonds $[2.568$ (5) and 2.574 (6) $\AA$ ] are of the same order of magnitude as the $\mathrm{O}$... O distances in the $\mathrm{H}_{2} \mathrm{AsO}_{4}$ tetrahedron [between 2.634 (6) and 2.791 (6) $\AA$ ] . Such distances along with the short As...As distance of 4.581 (1) $\AA$ allow us to consider the $\left[\mathrm{H}_{4} \mathrm{As}_{2} \mathrm{O}_{8}\right]_{\mathrm{n}}{ }^{2 \mathrm{n}-}$ network as a polyanion. This result has also been noticed in other crystal structures $[12,13]$. The interconnection between two adjacent anions $\mathrm{H}_{2} \mathrm{AsO}_{4}{ }^{-}$ is assured by a strong $\mathrm{H}$-bond $[\mathrm{d}(\mathrm{O} \cdots \mathrm{O})<2.73 \AA$ ] [14]. The calculated average values of distortion indices correspond to the different angles and distances in the $\mathrm{AsO}_{4}$ tetrahedron [15]. $[\mathrm{DI}(\mathrm{OAsO})=0.0255 ; \mathrm{DI}(\mathrm{AsO})=0.0132 ;$ and $\mathrm{DI}(\mathrm{OO})=$ 0.0135] exhibit a slight distortion of the $\mathrm{OAsO}$ angles if compared to $\mathrm{O}-\mathrm{O}$ and As-O distances. So, the AsO $\mathrm{O}_{4}$ group can be considered as a rigid regular arrangement of oxygen atoms, with the arsenic atom slightly displaced from the gravity center. Fig. 5 displays the crystal structure viewed in the (b, c) plane. This projection shows that each inorganic dimer is connected to two organic cations building inorganic clusters with the formula $\left[\mathrm{C}_{12} \mathrm{H}_{13} \mathrm{~N}_{2} \mathrm{O}_{2}\left[\mathrm{H}_{2} \mathrm{As}_{2} \mathrm{O}_{8}\right]\right.$. Fig. 6 shows that the organic entities, trapped in the interlayer spacing perform the one-dimensional network cohesion through $\mathrm{N}-\mathrm{H}$...O hydrogen bonds. All the $\mathrm{D}$ (donor) $-\mathrm{H}$...A(acceptor) hydrogen bonds are listed in Table 3, with an upper limit of 2.926 (5) $\AA$ for $\mathrm{D}$...A distances and a lower limit of $164^{\circ}$ for $\mathrm{D}-\mathrm{H}$....A bond angles. These values are in good agreement with those observed in such anions in other dihydrogen-arsenates [16]. In the organic molecule, the carbon atoms of the pyridine ring built by $\mathrm{C} 1, \mathrm{~N} 2, \mathrm{C} 2, \mathrm{C} 3, \mathrm{C} 4$, and $\mathrm{C} 5$ atoms (ring A) and the aromatic ring formed by $\mathrm{C} 7, \mathrm{C} 8, \mathrm{C} 9, \mathrm{C} 10$, C11, and C12 (ring B) are planar (r.m.s. deviation of fitted atoms equal to $0.0027 \AA$ for ring $A$ and $0.0073 \AA$ for ring $B$ ). The dihedral angle between the pyridine ring plane and benzene ring plane is $83.82^{\circ}$. Furthermore, the mean value of the $C-C$ bond lengths is equal to $1.382 \AA$, being the distance between single bond and double bond, which agrees well with that in benzene [17]. Besides, the C-N, C-C bond lengths vary from 1.308 (6) to 1.499 (7) $\AA$, the $\mathrm{C}-\mathrm{C}-\mathrm{N}, \mathrm{C}-\mathrm{C}-\mathrm{C}$ angles are included between 120.9 (5) and $122.1(7)^{\circ}$, and C-C-O, C-O-C angles spread from $112.2(4)$ to129.0 (4) ${ }^{\circ}$. The crystal structure exhibits two types of hydrogen bonds, the first of which, $\mathrm{O}-\mathrm{H}$... O, involve two short contacts with $\mathrm{H}$... O distances, ranging from 1.76 (3) to 1.78 (4) $\AA$. This type connects the acidic anions giving rise to the anionic chains. The second one, $\mathrm{N}-\mathrm{H}$...O bonds, with $\mathrm{H}$... O distances ranging from 1.76 (3) to 2.07 (4) A establishes the contact of organic cations with the anionic chains. This atomic arrangement includes four hydrogen bond donors (two $\mathrm{N}$ and two $\mathrm{O}$ atoms) and two hydrogen bond acceptors $(\mathrm{O}(1)$ and $\mathrm{O}(3)$ atoms $)$. 
Table 2 Main interatomic distances $(\AA)$ and angles $\left(^{\circ}\right)$ in $\left[\mathrm{C}_{12} \mathrm{H}_{13} \mathrm{~N}_{2} \mathrm{O}\right] \mathrm{H}_{2} A s \mathrm{O}_{4}$ atomic arrangement

\begin{tabular}{|c|c|c|c|c|}
\hline \multicolumn{5}{|l|}{$\mathrm{H}_{2} \mathrm{AsO}_{4}$ Tetrahedron } \\
\hline As & 01 & $\mathrm{O} 2$ & $\mathrm{O} 3$ & $\mathrm{O} 4$ \\
\hline 01 & $1.659(3)$ & $111.4(2)$ & $111.7(2)$ & $110.9(2)$ \\
\hline $\mathrm{O} 2$ & $2.778(6)$ & $1.702(4)$ & $109.3(2)$ & $101.1(2)$ \\
\hline O3 & $2.746(6)$ & $2.744(7)$ & $1.662(4)$ & $112.0(2)$ \\
\hline $\mathrm{O} 4$ & $2.770(6)$ & $2.634(6)$ & $2.791(6)$ & $1.708(3)$ \\
\hline $\mathrm{O} 2-\mathrm{H}(\mathrm{O} 2)=0.820$ & & As-O2- $\mathrm{H}(\mathrm{O} 2)$ & & \\
\hline $\mathrm{O} 4-\mathrm{H}(\mathrm{O} 4)=0.820$ & & As- $-\mathrm{O} 4-\mathrm{H}(\mathrm{O} 4)$ & & \\
\hline \multicolumn{5}{|l|}{ Organic cation } \\
\hline $\mathrm{C} 1-\mathrm{N} 1$ & $1.308(6)$ & $\mathrm{O} 5-\mathrm{C} 6$ & $1.448(5)$ & \\
\hline $\mathrm{C} 1-\mathrm{N} 2$ & $1.334(6)$ & $\mathrm{C} 6-\mathrm{C} 7$ & $1.499(7)$ & \\
\hline C1-C5 & $1.419(6)$ & $\mathrm{C} 7-\mathrm{C} 8$ & $1.369(7)$ & \\
\hline $\mathrm{N} 2-\mathrm{C} 2$ & $1.356(6)$ & $\mathrm{C} 7-\mathrm{C} 12$ & $1.384(7)$ & \\
\hline $\mathrm{C} 2-\mathrm{C} 3$ & $1.351(6)$ & $\mathrm{C} 8-\mathrm{C} 9$ & $1.376(9)$ & \\
\hline $\mathrm{C} 3-\mathrm{C} 4$ & $1.392(7)$ & $\mathrm{C} 9-\mathrm{C} 10$ & $1.306(1)$ & \\
\hline C4-C5 & $1.359(7)$ & $\mathrm{C} 10-\mathrm{C} 11$ & $1.356(1)$ & \\
\hline $\mathrm{C} 5-\mathrm{O} 5$ & $1.352(6)$ & $\mathrm{C} 11-\mathrm{C} 12$ & $1.407(1)$ & \\
\hline $\mathrm{N} 1-\mathrm{C} 1-\mathrm{N} 2$ & $121.2(4)$ & $\mathrm{C} 5-\mathrm{O} 5-\mathrm{C} 6$ & $119.0(4)$ & \\
\hline $\mathrm{N} 1-\mathrm{C} 1-\mathrm{C} 5$ & $120.9(5)$ & $\mathrm{O} 5-\mathrm{C} 6-\mathrm{C} 7$ & $112.7(4)$ & \\
\hline $\mathrm{N} 2-\mathrm{C} 1-\mathrm{C} 5$ & $117.9(4)$ & $\mathrm{C} 8-\mathrm{C} 7-\mathrm{C} 12$ & $118.2(5)$ & \\
\hline $\mathrm{C} 1-\mathrm{N} 2-\mathrm{C} 2$ & $123.3(4)$ & $\mathrm{C} 8-\mathrm{C} 7-\mathrm{C} 6$ & $121.7(5)$ & \\
\hline $\mathrm{C} 3-\mathrm{C} 2-\mathrm{N} 2$ & $120.0(5)$ & $\mathrm{C} 12-\mathrm{C} 7-\mathrm{C} 6$ & $120.1(5)$ & \\
\hline $\mathrm{C} 2-\mathrm{C} 3-\mathrm{C} 4$ & $118.7(5)$ & $\mathrm{C} 7-\mathrm{C} 8-\mathrm{C} 9$ & $120.7(6)$ & \\
\hline $\mathrm{C} 5-\mathrm{C} 4-\mathrm{C} 3$ & $121.2(4)$ & $\mathrm{C} 10-\mathrm{C} 9-\mathrm{C} 8$ & $122.1(7)$ & \\
\hline $\mathrm{O} 5-\mathrm{C} 5-\mathrm{C} 4$ & $129.0(4)$ & $\mathrm{C} 9-\mathrm{C} 10-\mathrm{C} 11$ & $119.3(7)$ & \\
\hline $\mathrm{O} 5-\mathrm{C} 5-\mathrm{C} 1$ & $112.2(4)$ & $\mathrm{C} 10-\mathrm{C} 11-\mathrm{C} 12$ & $121.2(6)$ & \\
\hline
\end{tabular}

Table 3 Principal interatomic distances $(\AA)$ and bond angles $\left(^{\circ}\right)$ and detailed of the hydrogen bonding scheme

\begin{tabular}{lcccc}
\hline $\mathbf{D}-\mathbf{H} \cdots \mathbf{A}$ & $\mathbf{D - H}$ & $\mathbf{H} \cdots \mathbf{A}$ & $\mathbf{D} \cdots \mathbf{A}$ & $\mathbf{D}-\mathbf{H} \cdots \mathbf{A}$ \\
\hline $\mathrm{O} 2-\mathrm{H}(\mathrm{O} 2) \cdots \mathrm{O}^{\prime}$ & 0.82 & 1.78 & $2.574(6)$ & 164 \\
$\mathrm{O} 4-\mathrm{H}(\mathrm{O} 4) \cdots$ 1" $^{\prime \prime}$ & 0.82 & 1.76 & $2.568(5)$ & 169 \\
$\mathrm{~N} 1-\mathrm{H} 1 \mathrm{~A} \cdots \mathrm{O} 3$ & 0.86 & 2.07 & $2.926(5)$ & 174 \\
$\mathrm{~N} 2-\mathrm{H} 2 \mathrm{~A} \cdots \mathrm{O} 1$ & 0.86 & 1.76 & $2.606(5)$ & 168 \\
\hline
\end{tabular}

Symmetry codes: (i) $x+1, y, z$; (ii) $x-1 / 2,-y+1 / 2,-z+2$, 


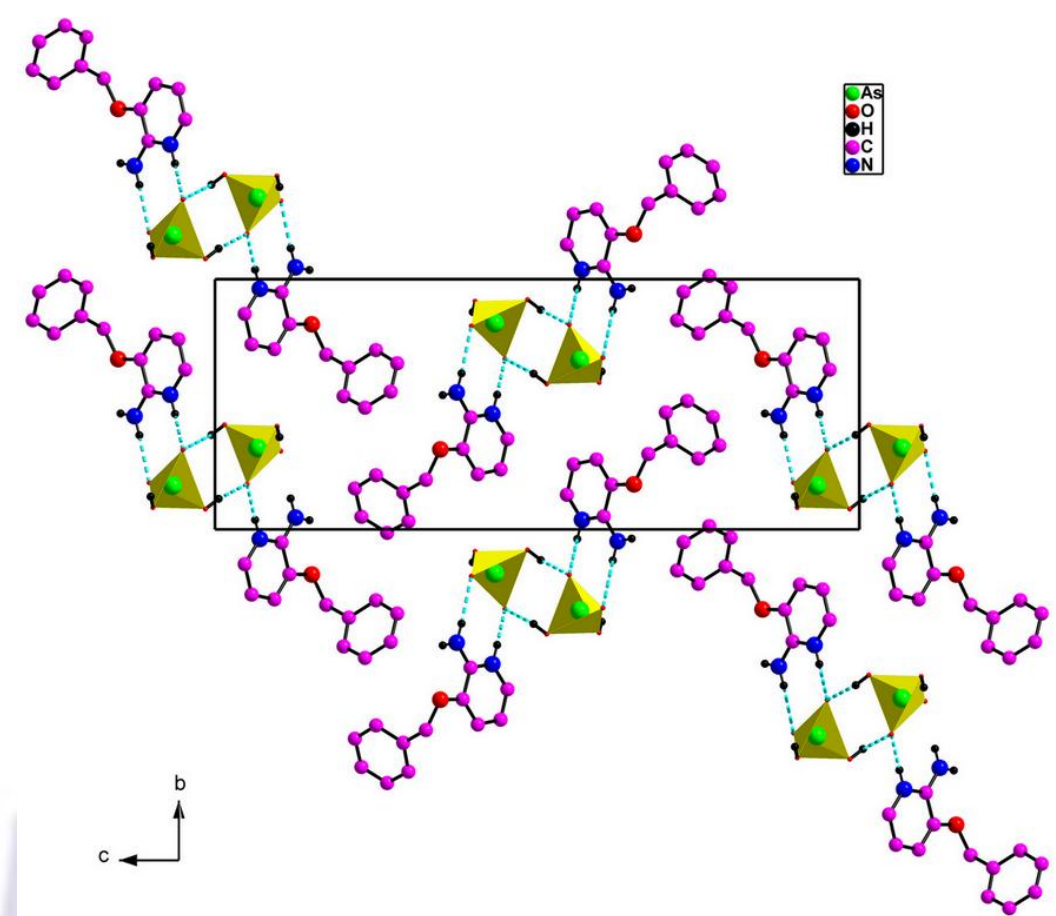

Fig. 5 Projection along the b-axis of the crystal structure of $\left[\mathrm{C}_{12} \mathrm{H}_{13} \mathrm{~N}_{2} \mathrm{O}\right] \mathrm{H}_{2} \mathrm{AsO}_{4}$.

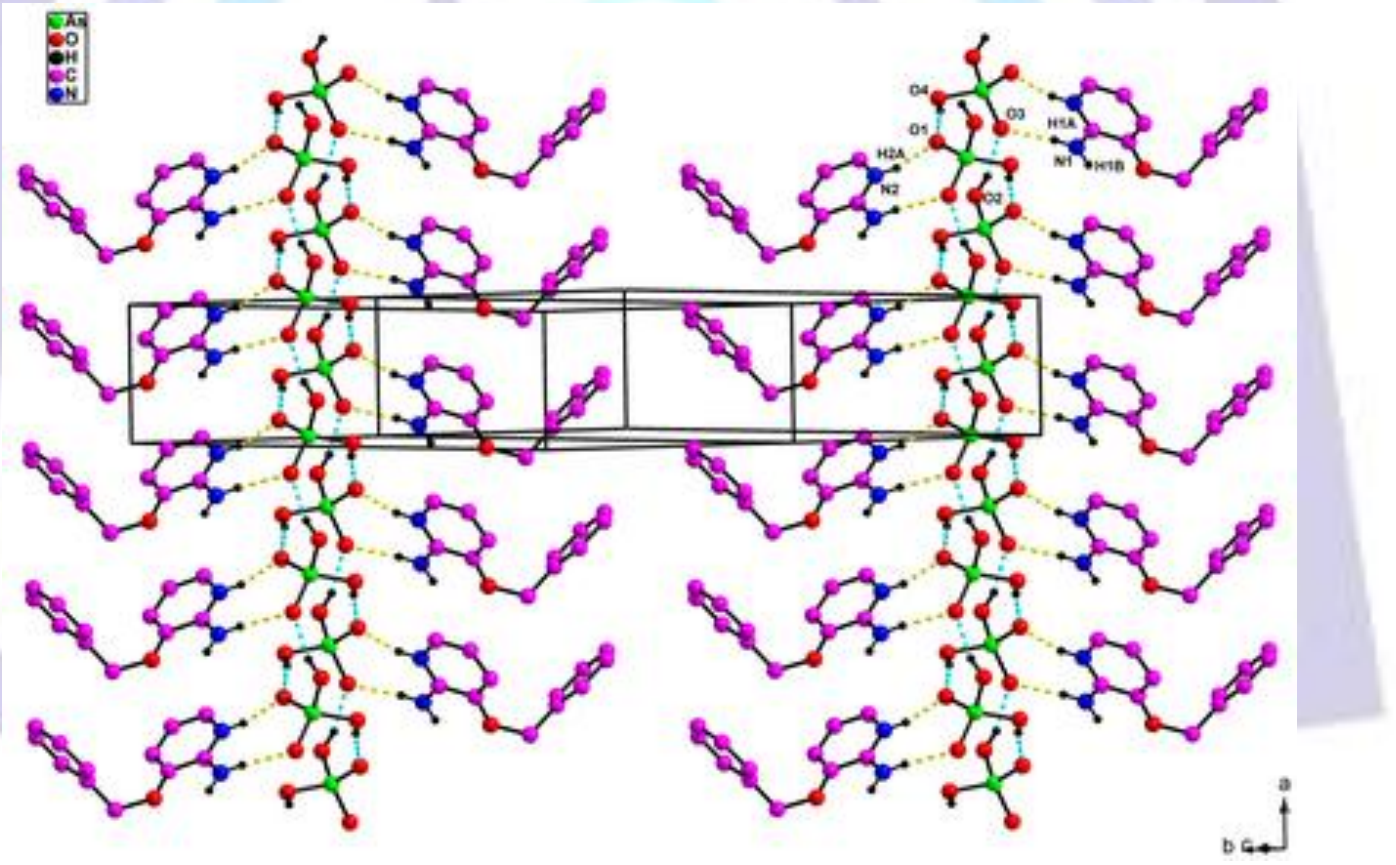

Fig. 6 Perspective viewing of the crystal structure of $\left[\mathrm{C}_{12} \mathrm{H}_{13} \mathrm{~N}_{2} \mathrm{O}\right] \mathrm{H}_{2} \mathrm{AsO}_{4}$.

\subsection{Vibrational study}

To confirm the X-ray structure results, we made use of NMR. The ${ }^{13} \mathrm{C}$ CP-MAS-NMR spectrum of the title compound displays nine different signals, (Fig. 7) corresponding to twelve carbon atoms of the organic cation. The first one, whose chemical shift is $68.8 \mathrm{ppm}$, is attributed to the methylene group found in the compound under study. The most shifted NMR components, whose chemical shifts range from 111.6 to $147.8 \mathrm{ppm}$, are attributed to the aromatic and pyridine carbon atoms. To assign NMR components to different carbon atoms, the chemical shifts have been calculated by means of the Chem Draw Ultra 6.0 software. The carbon atoms are labeled in Figure 1. The obtained results, gathered in Table 4, prove the presence of only one organic moiety in the asymmetric unit of the compound which agrees well with the X-ray diffraction data. 


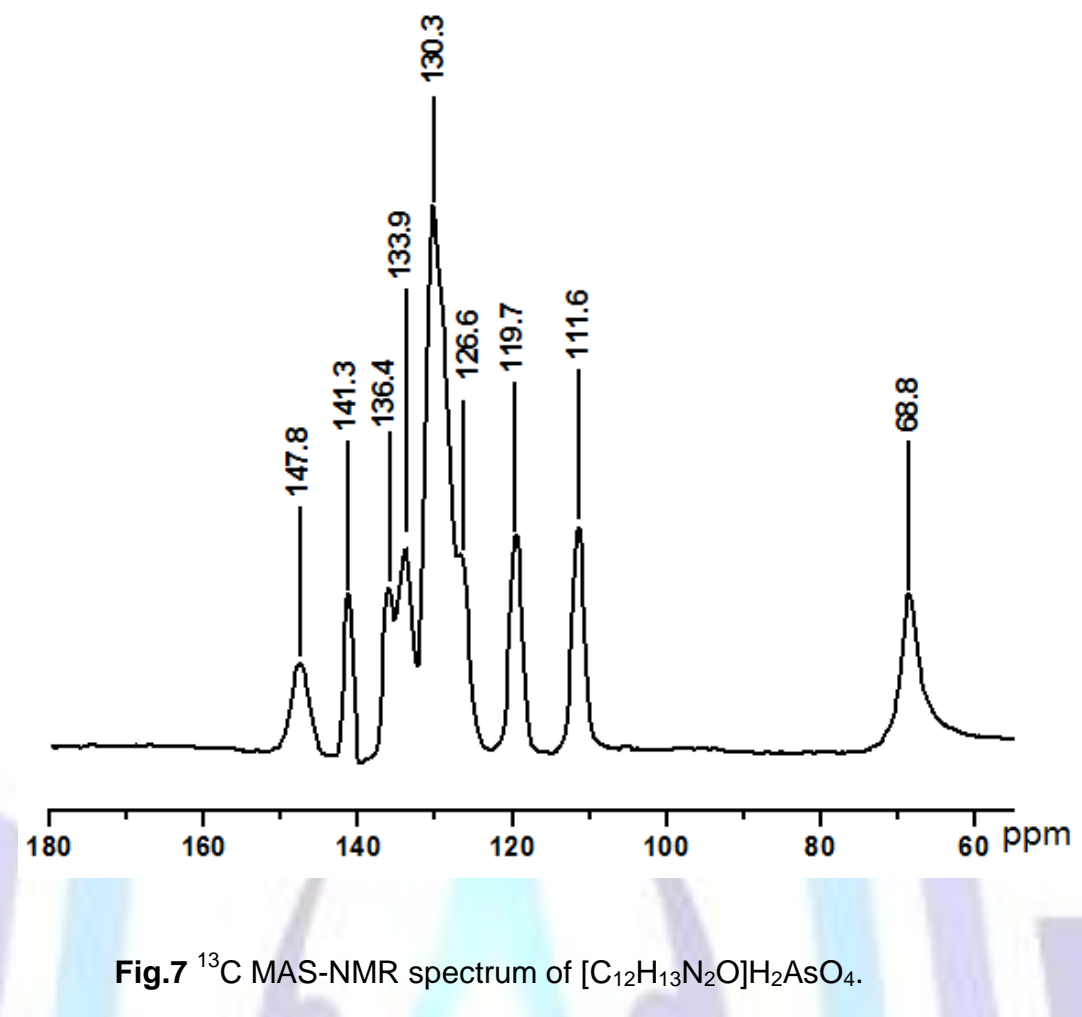

Table 4 Calculated and experimental chemical shifts of the carbon atoms of the organic cation.

\begin{tabular}{lcccccccccc}
\hline $\begin{array}{l}\text { Carbon } \\
\text { Atoms }\end{array}$ & C6 & C3 & C4 & $\begin{array}{c}\text { C8 and } \\
\text { C12 }\end{array}$ & C10 & $\begin{array}{c}\text { C9 and } \\
\text { C11 }\end{array}$ & C2 & C7 & C5 & C1 \\
$\delta_{\text {cal. }}(\mathrm{ppm})$ & 70.9 & 113.5 & 122.3 & 127.2 & 127.7 & 129.0 & 139.8 & 141.2 & 141.6 & 148.6 \\
$\delta_{\text {exp. }}(\mathrm{ppm})$ & 68.8 & 111.6 & 119.7 & 126.6 & 130.3 & 133.9 & 136.4 & 141.3 & 147.8 \\
\hline
\end{tabular}

Since IR and Raman spectroscopies are one of the major physical methods for the investigation of molecular structures, they were used in the study of the crystalline compound $\left[\mathrm{C}_{12} \mathrm{H}_{13} \mathrm{~N}_{2} \mathrm{O}\right] \mathrm{H}_{2} \mathrm{AsO}_{4}$, which are shown in Fig. 8 and 9 , respectively. To assign the IR and Raman peaks to the vibrational modes, the modes and frequencies observed in similar compounds were examined [18]. The assignments of the observed bands are listed in Table 5. The unperturbed $\left[\mathrm{AsO}_{4}\right]^{3-}$ tetrahedron with an ideal $T_{d}$ symmetry has four vibrational modes; the non-degenerate $v_{1}$, the doubly degenerate $v_{2}$, and the triply degenerate $v_{3}$ and $v_{4}$. These modes are observed at $837,349,878$, and $463 \mathrm{~cm}^{-1}$, respectively [19]. All of these modes are Raman active except for the triply degenerate modes $v_{3}$ and $v_{4}$ are infrared active. The localization of two protons on two of the oxygen atoms and the effect of its interaction with its crystalline environment, the $\left[\mathrm{H}_{2} \mathrm{AsO}_{4}\right]^{-}$anion in the studied compound can lose its symmetry and the degeneracy of its vibrational modes is then expected to be moved. This means that the observed splitting of bands into two or three components around the ideal values of the $v_{2}, v_{3}$, and $v_{4}$ modes cited above can be a useful criterion for assigning these modes. Consequently, the intense peaks situated at 978 , $1059 \mathrm{~cm}^{-1}$ and $1000,1028,1055 \mathrm{~cm}^{-1}$ in the IR and Raman spectra, respectively, are assigned to the symmetric stretching vibration $\mathrm{v}_{3}$ of $\mathrm{H}_{2} \mathrm{AsO}_{4}$, while the line which appears at $883 \mathrm{~cm}^{-1}$ is attributed to the symmetric stretching $\mathrm{v}_{1}$. This vibration mode is observed as two peaks around 866 and $840 \mathrm{~cm}^{-1}$ in the Raman spectrum. The bands located in the region $650-$ $500 \mathrm{~cm}^{-1}$ are attributed to the asymmetric bending $\mathrm{v}_{4}$ mode. Next, the strong peak at $416 \mathrm{~cm}^{-1}$ in the IR spectrum is assigned to the $v_{2}$ mode. The broad bands with frequencies in the range of 3600 and $2600 \mathrm{~cm}^{-1}$ are attributed to the stretching of the organic and hydroxyl groups $(\mathrm{v}(\mathrm{N}-\mathrm{H}), \mathrm{v}(\mathrm{C}-\mathrm{H}))$, and $v(\mathrm{O}-\mathrm{H})$ of As-OH groups. The ABC type bands characteristic of the $\mathrm{OH}$ modes in the $\left(\mathrm{H}_{2} \mathrm{AsO}_{4}\right)$ groups are barely perceived between 2600 and $1700 \mathrm{~cm}^{-1}$. The observed bands at $1665,1556 \mathrm{~cm}^{-1}$ in IR and 1604,1586 and $1560 \mathrm{~cm}^{-1}$ in Raman are assigned to the bending modes of the $\mathrm{NH}_{2}$ moiety $\left(\delta_{a s}\left(N_{2}\right)\right.$ and $\delta_{s}\left(N_{2}\right)$, respectively). The intense band around $1394 \mathrm{~cm}^{-1}$ is assigned to the $v(C=C)$. The band which appears at $1480 \mathrm{~cm}^{-1}$ is attributed to the bending mode $\delta\left(\mathrm{CH}_{2}\right)$. The lines situated in $1300-1100 \mathrm{~cm}^{-1}$ are assigned to $v(\mathrm{C}-\mathrm{N}), v(\mathrm{C}-\mathrm{C}), \delta(\mathrm{C}-\mathrm{H}), \quad \delta(\mathrm{N}-\mathrm{H})$ and $\delta(\mathrm{OH})$. 


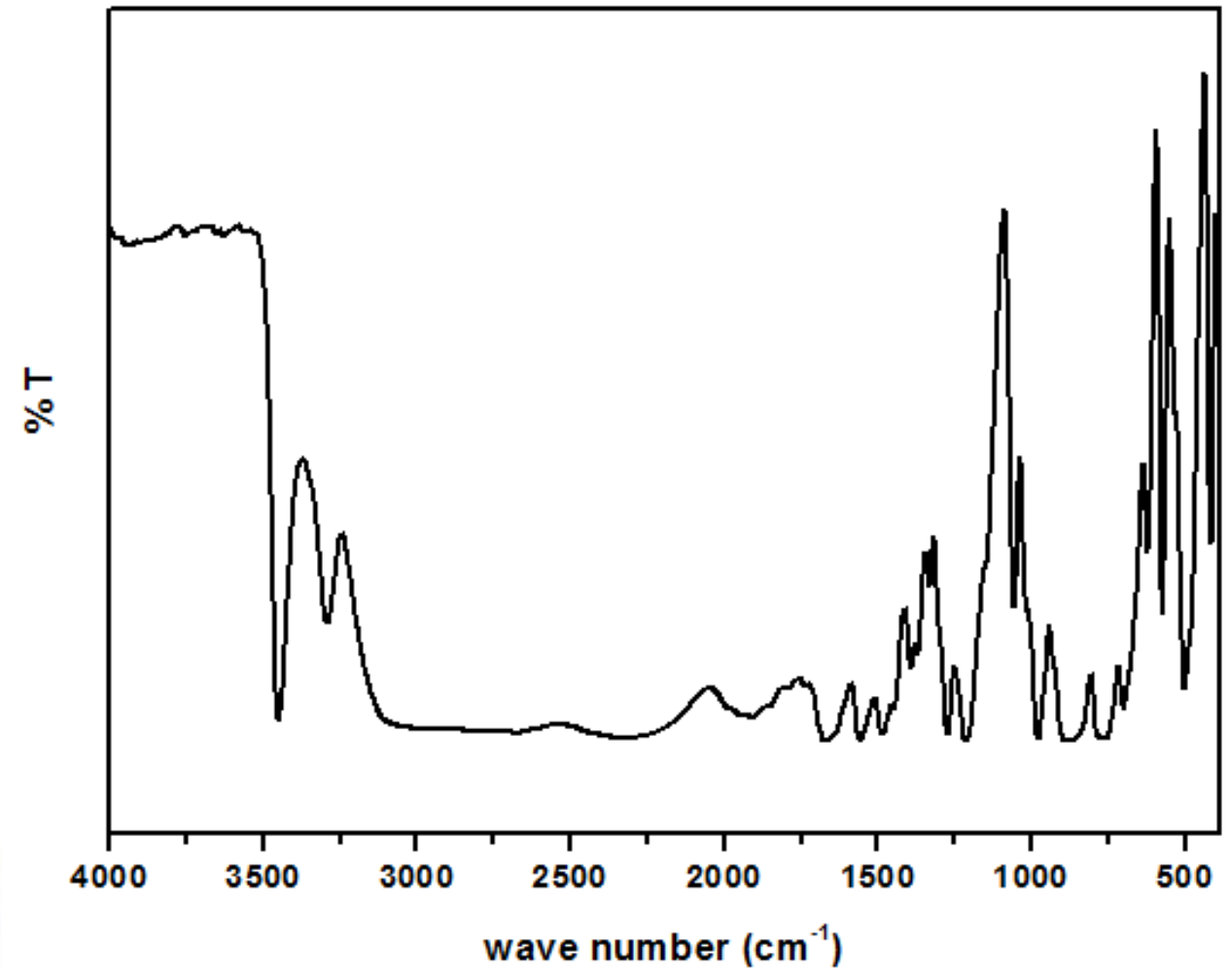

Fig.8 IR spectrum of $\left[\mathrm{C}_{12} \mathrm{H}_{13} \mathrm{~N}_{2} \mathrm{O}\right] \mathrm{H}_{2} \mathrm{AsO}_{4}$.

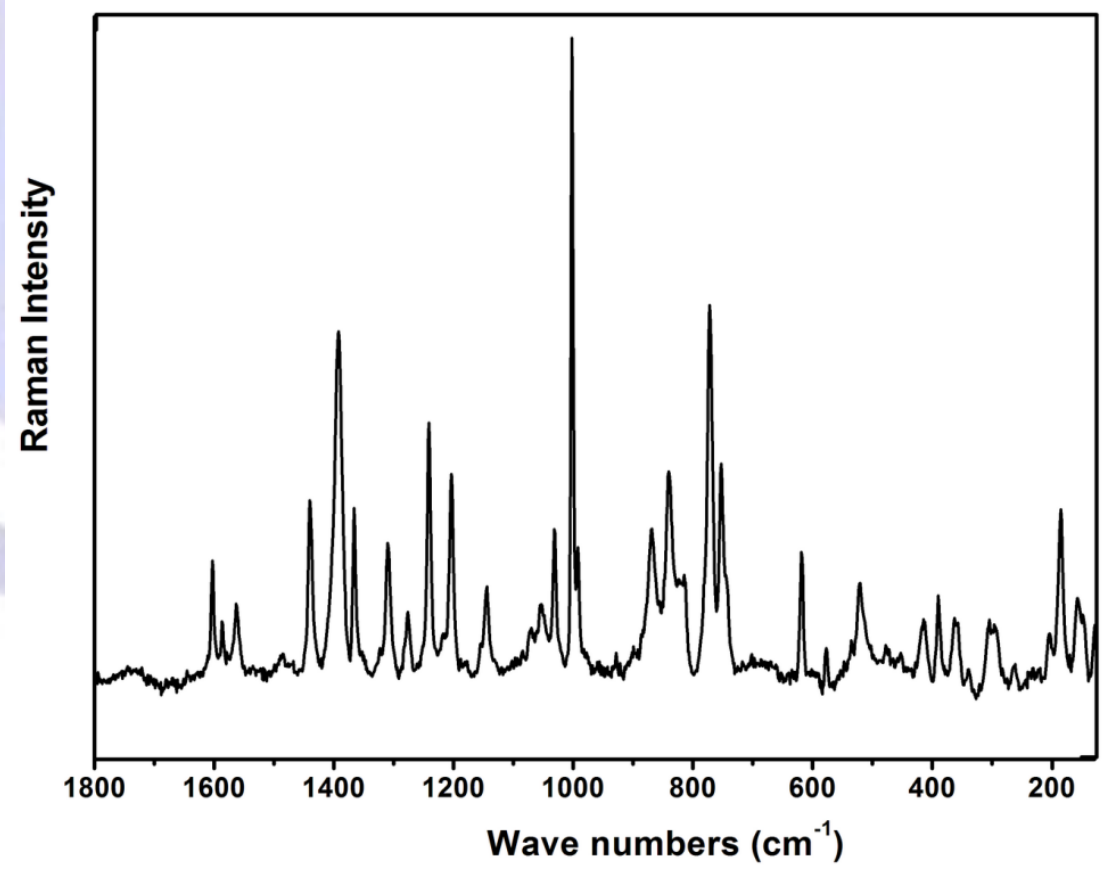

Fig. 9 Raman spectrum of $\left[\mathrm{C}_{12} \mathrm{H}_{13} \mathrm{~N}_{2} \mathrm{O}\right] \mathrm{H}_{2} \mathrm{AsO}_{4}$. 
Table 5 Infrared and raman spectral data $\left(\mathrm{cm}^{-1}\right)$ and band assignments for $\left[\mathrm{C}_{12} \mathrm{H}_{13} \mathrm{~N}_{2} \mathrm{O}\right] \mathrm{H}_{2} \mathrm{AsO}_{4} \mathrm{sample}_{\text {. }}$

\begin{tabular}{|c|c|c|c|}
\hline IR wavenumbers $\left(\mathrm{cm}^{-1}\right)$ & Raman wavenumbers $\left(\mathrm{cm}^{-1}\right)$ & Assignement & \\
\hline 3456 vs & - & $v(\mathrm{OH})$ & \\
\hline $3294 \mathrm{~s}$ & - & $v_{\mathrm{s}}(\mathrm{NH})$ & \\
\hline $2600-3000 \mathrm{~L}$ & - & $v_{\mathrm{as}}(\mathrm{NH})+v(\mathrm{C}-\mathrm{H})$ & \\
\hline $2530-1922 \mathrm{~s}$ & - & $v(\mathrm{OH})$ “A + B + C" & \\
\hline $1665 \mathrm{~s}$ & $1604 \mathrm{w}$ & $\delta_{\mathrm{as}}\left(\mathrm{NH}_{2}\right)$ & \\
\hline $1556 \mathrm{~s}$ & $1586 \mathrm{vw}-1560 \mathrm{vw}$ & $\delta_{\mathrm{s}}\left(\mathrm{NH}_{2}\right)$ & \\
\hline $1480 \mathrm{~s}$ & $1443 \mathrm{~m}$ & $\delta\left(\mathrm{CH}_{2}\right)$ & \\
\hline $1394 \mathrm{~m}$ & $1393 \mathrm{~s}$ & $v(\mathrm{C}=\mathrm{C})$ & \\
\hline $1330 \mathrm{~m}$ & $1366 \mathrm{~m}-1309 \mathrm{~m}$ & $\mathrm{w}\left(\mathrm{CH}_{2}\right)$ & \\
\hline 1273 vs & $1277 \mathrm{~m}-1242 \mathrm{~m}$ & $v(\mathrm{C}-\mathrm{N})+v(\mathrm{C}-\mathrm{C})+\delta(\mathrm{C}-\mathrm{H})$ & $+\delta(\mathrm{N}-$ \\
\hline 1214 vs & $1206 \mathrm{~m}-1147 \mathrm{w}$ & $\mathrm{H})$ and $\delta(\mathrm{OH})$ & \\
\hline $1059 \mathrm{~m}$ & $1055 \mathrm{vw}$ & & \\
\hline 978 vs & $1028 \mathrm{w}$ & $v_{3}\left(\mathrm{AsO}_{4}\right)$ & \\
\hline- & 1000 vs & & \\
\hline 883 vs & $866 m-840 m$ & $v_{1}\left(\mathrm{AsO}_{4}\right)$ & \\
\hline 762 vs & $771 \mathrm{~s}$ & $\mathrm{r}\left(\mathrm{CH}_{2}\right)$ & \\
\hline 696 vs & $751 \mathrm{~m}$ & & \\
\hline $624 \mathrm{~s}$ & $617 \mathrm{~m}$ & & \\
\hline $573 \mathrm{~s}$ & $519 w$ & $v_{4}\left(\mathrm{AsO}_{4}\right)$ & \\
\hline $497 \mathrm{~s}$ & - & & \\
\hline $416 \mathrm{~m}$ & $417 w$ & $v_{2}\left(\mathrm{AsO}_{4}\right)$ & \\
\hline - & $389 w$ & & \\
\hline
\end{tabular}

vs: very strong; s: strong; m: medium; w: weak ; vw : very weak; L: large.

\subsection{Electrical Conductivity}

The study of the dielectric properties is an important source for valuable information about conduction processes [20]. Fig. 10 shows the plot of (-Z") versus Z' taken over the frequency range (209 Hz to $5 \mathrm{MHz}$ ) at different temperatures ( $299 \mathrm{~K} \leq \mathrm{T} \leq 403 \mathrm{~K}$ ). The values of bulk resistance $(R)$ at different temperatures have been obtained from the intercept of the semicircular arcs, observed at a low frequency, on the real axis $\left(Z^{\prime}\right)$. It is observed that $(R)$ decreases with rise in the temperature. The electrical conductivity $\sigma$ was obtained from $(R)$ by means of the relation: $\sigma=$ e/RS where (e/S) represents the sample geometrical ratio. The temperature dependence of the conductivity between 299 and $403 \mathrm{~K}$ is represented in Fig. $11\left(\mathrm{Ln}(\sigma \mathrm{T})\right.$ versus $\left.10^{3} / \mathrm{T}\right)$. In this range of temperature, the electrical conductivity increases with increasing temperature. However, the conductivity obeys approximately to the Arrhenius behavior given by $\sigma \mathrm{T}=\exp (-$ $\left.\mathrm{Ea} / \mathrm{K}_{\mathrm{b}} \mathrm{T}\right)$ in the range 299 and $403 \mathrm{~K}$. The conductivity plot, in this region, exhibits one part. The activation energy is $(\mathrm{Ea}=$ $0.33 \mathrm{eV}$ ). This seems to indicate only one protonic conductivity mechanism and there is no modification of the electrical proprieties. These results are in good agreement with the calorimetric study, which does not show any phase transition before the melting point.

In summary, the electric properties of this hybrid compound may be interpreted by the following way: The rise of temperature can favor the vibration of the inorganic chains, which induce a rapid reorientation of $\mathrm{H}_{2} \mathrm{AsO}_{4}^{-}$and fast $\mathrm{H}^{+}$ moving [21]. The fact that the $\mathrm{OH}$ groups belonging to the arsenate anions form infinite chains is strongly in favor of a protonic mobility between the oxygens of the arsenate anions. Indeed, the $\mathrm{H}_{2} \mathrm{AsO}_{4}{ }^{-}$anion performs both as proton donor and acceptor, by its four oxygen atoms, thus producing an extended intermolecular $\mathrm{H}$-bonds network, through which structural migration of proton may occur via Grotthus mechanism [22]. The literature provides many examples of this type of situation $[23,24]$. 


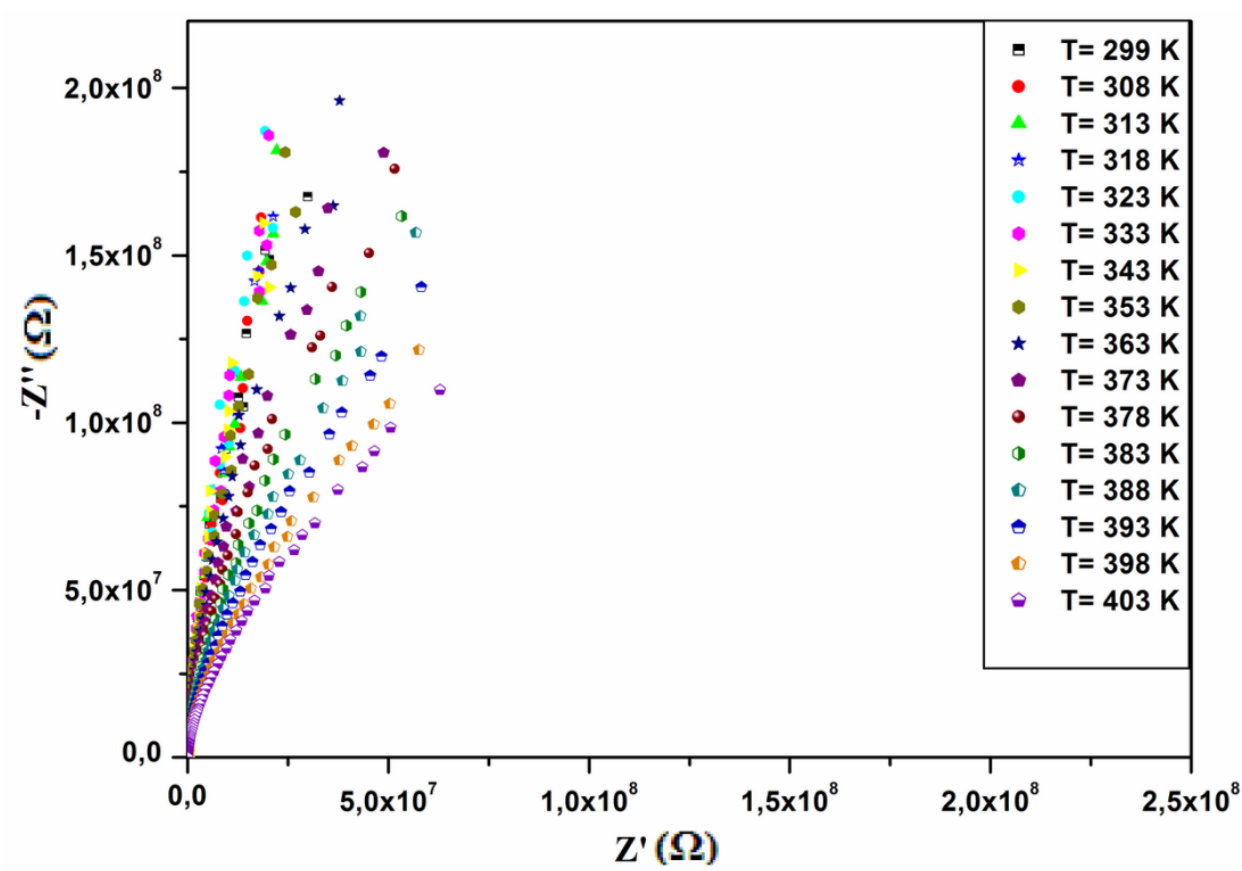

Fig. 10 Complex impedance spectra as a function of temperature.
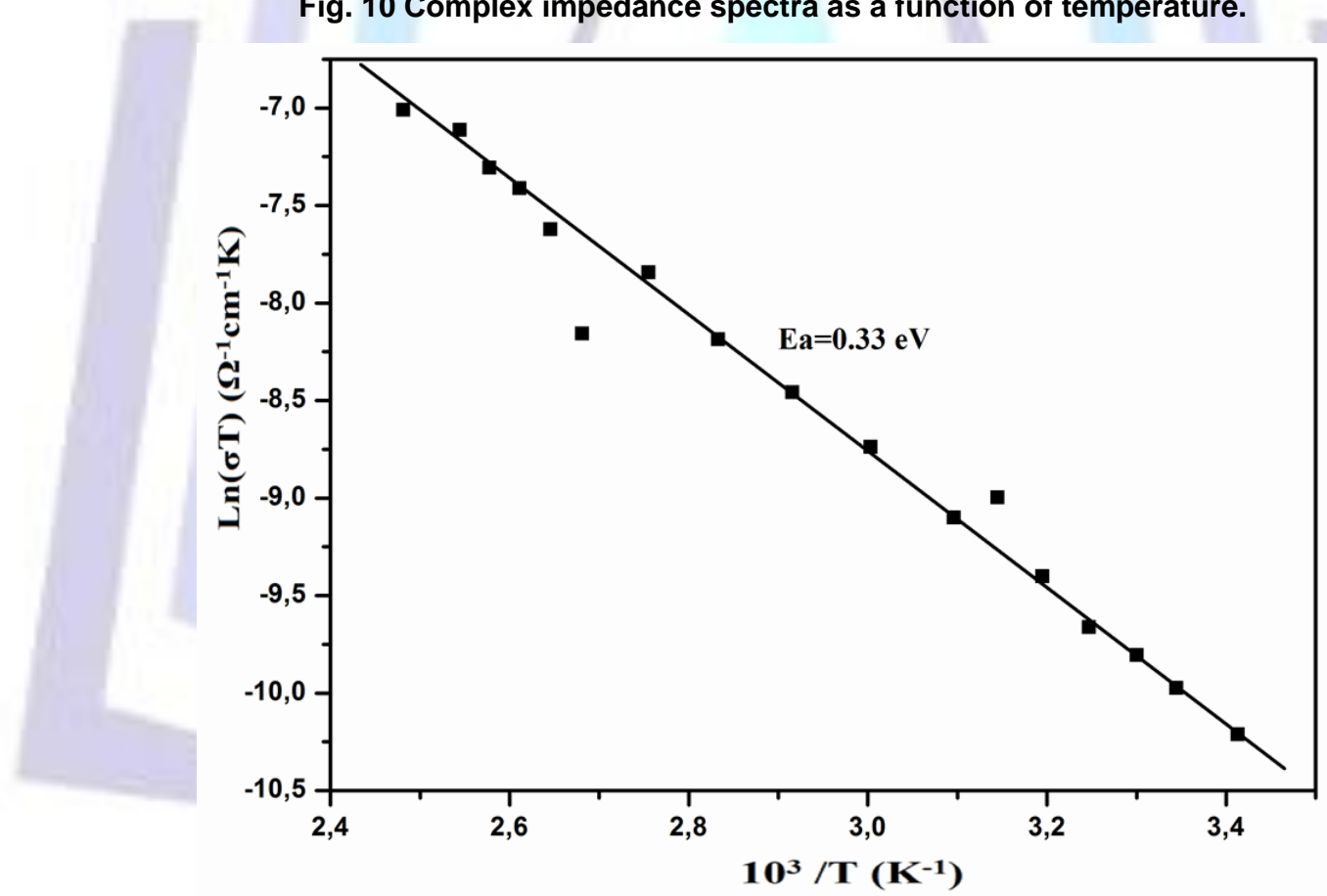

Fig. 11 Arrhenius plot of the electrical conductivity of $\left[\mathrm{C}_{12} \mathrm{H}_{13} \mathrm{~N}_{2} \mathrm{O}\right] \mathrm{H}_{2} \mathrm{AsO} \mathrm{O}_{4}$.

\section{CONCLUSION}

A novel organic-inorganic hybrid compound, $\left[\mathrm{C}_{12} \mathrm{H}_{13} \mathrm{~N}_{2} \mathrm{O}\right] \mathrm{H}_{2} \mathrm{AsO}_{4}$ has been successfully synthesized at room temperature by slow evaporation. This compound has been characterized by various physico-chemical methods. On the structural level, the atomic arrangement of the title compound can be described by infinite anionic chains running parallel to the [100] direction. The organic cations are linked to the inorganic chains by $\mathrm{N}-\mathrm{H} \ldots \mathrm{O}$ hydrogen bonds. Moreover, the FT-IR and Raman spectra have been recorded in the range of [400-4000] and [200-1800] $\mathrm{cm}^{-1}$ gives the detail about the various functional groups constituting our material. The number of solid-state ${ }^{13} \mathrm{C}$ MAS NMR components agrees perfectly with the ones of cristallographically independent sites. Indeed, it is to be noted that this compound was stable until $134^{\circ} \mathrm{C}$. After heating at $400^{\circ} \mathrm{C}$, a viscous matter of polyarsenic acid with a carbon black residue was obtained. Moreover, the temperature dependence of resistance, proving the good conduction properties of the compound under study. The transport mechanism arises from protons jumping between the anionic chains. The activation energy for the title compound is $\mathrm{Ea}=0.33 \mathrm{eV}$, suggesting that the protonic transport is probably due to a Grotthus mechanism. 


\section{REFERENCES}

[1] J.T. Wang, R.F. Savinell, J. Wainright, M. Litt, H. Yu, Electrochimica Acta. 41, 193 (1996).

[2] N. Coombs, D. Khuehniani, S. Oliver, G. A. Ozin, G. C. Shen, I. Sokolov, H. Yang, J. Chem. Soc., Dalton Trans. 21, 3941 (1997).

[3] R. Masse, M. Bagieu-Beucher, J. Pecaut, J. P. Levy, J. Zyss, Nonlinear Opt. 5, 413 (1993).

[4] L. Baoub, A. Jouini, J Solid State Chem. 141, 343 (1998).

[5] A. Rayes, C. Ben Nasr, M. Rzaigui, Mater Res Bull. 39, 1113 (2004).

[6] K. Kaabi, C. Ben Nasr, M. Rzaigui, J Phys Chem Solids. 65, 1759 (2004).

[7] K. Kaabi, A. Rayes, C. Ben Nasr, M. Rzaigui, F. Lefebvre, Mater Res Bull. 38, 741 (2003).

[8] G.M. Sheldrick, SHELXS-97 Program for the Solution of Crystal Structures, University of Göttingen, Germany, 1997

[9] G.M. Sheldrick, SHELXL-97 Program for Crystal Structure Refinement, University of Göttingen, Germany, 1997

[10] S. Akriche, M. Rzaigui, Acta Cryst. E63, o3460 (2007).

[11] C.-H. Lin, N.S. Liu, F.F. Jian, Acta Cryst. E65, 02639 (2009).

[12] A. Chtioui, L. Benhamada, A. Jouini, Mater. Res. Bull. 40, 2243 (2005).

[13] A. Chtioui, A. Jouini, Mater. Res. Bull. 41, 569 (2006).

[14] I. D. Brown, Acta Cryst. A32, 24 (1976).

[15] W. H. Baur, Acta Cryst. B30, 1195 (1974).

[16] A. Chtioui, L. Benhamada, S. Belghith, A. Jouini, Mater. Res. Bull. 45, 1692 (2010).

[17] Z. J. Li, X. M. Chem, Z. X. Ren, Y. Li, X. A. Chem, Z. T. Huang, Chinese J. Struct. Chem. 16, 311 (1997).

[18] A. Oueslati, A. Rayes, C. Ben Nasr, F. Lefebvre, Mater. Res. Bull. 40, 1680 (2005).

[19] K. Nakamoto, Infrared and Raman Spectra of Inorganic and Coordination Compounds; Wiley-Interscience, 1986

[20] R. Ayouchi, D. Leien, F. Martin, M. Gabas, E. Dalchiele, J.R. Ramos Barrodo, Thin Solid Films. 426, 68 (2003).

[21] A. Schechter, R.F. Savinell, Solid State lonics. 147, 181 (2002).

[22] O. Labidi, P. Roussel, M. Huve, M. Drache, P. Conflant, J.P. Wignacourt, J. Solid State Chem. 178, 2247 (2005).

[23] I. Ben Djema, Z. Elaoud, T. Mhiri, R. Abdelhedi, Jean Michel. Savariault. Solid State Commun, 142, 610 (2007).

[24] Z. Elaoud, S. AL-Juaid, T. Mhiri, A. Daoud. J. Alloy. Compd., 442, 306 (2007). 